\title{
Meta Analysis the Effect of Body Mass Index on the Flat Foot Incidence
}

\author{
Philipus Prihantiko Kurniagung1), Dono Indarto²), Setyo Sri Rahardjo²) \\ 1) Masters Program in Public Health, Universitas Sebelas Maret \\ 2)Faculty of Medicine, Universitas Sebelas Maret
}

ABSTRACT

\begin{abstract}
Background: Musculoskeletal disorders in the form of flat foot, back pain and knee pain are often found in people who are obese. Flat foot is a musculoletal disorder characterized by a decrease or decrease in the height of the medial arch as a parameter, especially those that can be observed and measured in height. This study aims to estimate the average size of the effect of BMI on the risk of flat foot.

Subjects and Method: Meta-analysis study and systematic reviews were applied to this study using the electronic database Pubmed, Science Direct, Google Scholar and Springer Link. Keywords to search for articles are as follows: "flat foot", "adult flat foot", "Flexible Flat Foot", "Body Mass Index", "Pediatric flat foot", "pes planus", "obesity", "overweight", "Adolescent flat foot". Articles were collected using PRISMA diagrams, and analyzed using the Review Manager 5.3 application.
\end{abstract}

Results: Meta-analysis of 4 cross-sectional articles of obese individuals $(\mathrm{aOR}=3.10 ; 95 \%$ $\mathrm{CI}=1.80$ to $5.32 \mathrm{p}=0.001$ ); Meta-analysis of 2 case-control articles, obese individuals $(\mathrm{aOR}=5.49 ; 95 \% \mathrm{CI}=1.33$ to $22.61 ; \mathrm{p}=0.07)$. Meta-analysis of 3 cohort articles of obese individuals $(\mathrm{aOR}=1.64 ; 95 \% \mathrm{CI}=1.34$ to 2.02; $\mathrm{p}<0.001)$; Obesity is a risk factor that can increase the incidence of flat foot.

Conclusion: Obesity is a risk factor that can increase the incidence of flat foot.

Keywords: Obesity, flat foot, risk factors

\section{Correspondence:}

Philipus Prihantiko Kurniagung. Masters Program in Public Health. Universitas Sebelas Maret. Jl. Ir. Sutami 36A, Surakarta 57126, Central Java, Indonesia. Email: prihantiko@gmail.com. Mobile:089688103450.

Cite this as:

Kurniagung PP, Indarto D, Rahardjo SS (2020). Meta Analysis the Effect of Body Mass Index on the Flat Foot Incidence. J Epidemiol Public Health. 05(03): 329-338. https://doi.org/10.26911/jepublichealth.2020.05.03.07.

(c) (i) Journal of Epidemiology and Public Healthis licensed under a Creative Commons Attribution-NonCommercial-ShareAlike 4.o International License.

\section{BACKGROUND}

Musculoskeletal flat foot disorders are usually followed by abnormalities in the hindfoot or pes planovalgus (Dare and Dodwell, 2014). Flat foot can happen to anyone but is common in babies, because the arch of the foot is not fully developed. However, the arch of the foot in infants begins to grow when standing and walking exercises to maintain body balance (Witari et al, 2019).

A study by Ezema et al. (2016) reported that $22.4 \%$ or 106 children of 474 children aged 6-10 years in 6 elementary schools in Enugu Metropolis, Nigeria experienced flat foot. Meanwhile, Fernandez et al (2017) stated that 213 out of 800 adults 40 years and over in Cambre, Spain also suffer from flat foot. (Ezema et al, 2016 and Fernandezet al, 2017). The prevalence of flat foot has also been studied by Witari et al. (2017) in Bali Province, Indonesia states that there are 5 primary schools with a child age range of 6-12 years. The number of samples used was 123 children and the number of children suffering from flat foot was 53 children or about $43 \%$. 
Further deformities caused by flat foot can range from mild to severe. Therefore, screening and early treatment of flat foot is very necessary because it can prevent the effects of flat foot that is not handled adequately. When the body is leaning on the body weight, the medial arch is not visible, while when the body is not leaning on, the medial arch can be seen, so this is known as a flexibleflat foot. If the body is supported or not, the medial arch is not visible, it is called rigid flat foot. Some literature states that flat foot can cause longterm effects such as pain in the soles of the feet and ankles as well as experiencing balance disturbances, both static and dynamic. In addition, flat foot can also cause further deformities such as bunions and hammertoes, and can result in repeated acute trauma that can change shape in the foot (Witari et al, 2019).

Many factors are associated with the incidence of flat foot, namely obesity, activity level, gender, joint hyper-mobility, age, sitting, and heredity (Chang et al, 2011; Abischet al, 2020).

Musculoskeletal disorders in the form of back pain and knee are often found in people who are obese. Not only knee and back problems, but other reported musculoskeletal disorders of the feet, obesity and overweight can interfere with development associated with certain foot dimorphisms, particularly flat foot. Obesity can change the structure of foot function and a number of mechanisms and can change biomechanics so that it can change gait parameters. Weight gain can also change the emphasis on the feet, causing pain (Butterwoth et al, 2012)..

\section{SUBJECTS AND METHOD}

\section{Study Design}

This study uses a systematic review, namely meta-analysis, meta-analysis. This research was conducted by selecting articles in several databases, namely Pubmed, Science Direct, Scopus, Google Scolar and Springer Link. The keywords used in the search were "flat foot", "adult flat foot", "Flexible Flat Foot", "Body Mass Index", "Pediatric flat foot”, "pes planus", "obesity”, "overweight", "Adolescent flat foot".

\section{Inclusion Criteria}

The classification of the inclusion criteria in this study is a full-text article with an observational study. Selected articles discuss risk factors for the incidence of flat foot in the pediatric to adult population. Articles published in English. Research data processing was carried out using multiple logistic regression.

\section{Exclusion Criteria}

The classification of the exclusion criteria in this study was the study carried out by RCT, quasi-experimental, and study protocol.

\section{Operational Definitionof variables}

Flat foot is the absence or reduction of the medial longitudinal arch of the foot.

Obesity is a disorder or disease characterized by excessive accumulation of fatty tissue

\section{Data Analysis}

Data processing was carried out using the Review Manager (RevMan 5.3) measured by the effect size and heterogeneity to determine the research merger model and form the final meta-analysis result on the Forest plot.

\section{RESULTS}

The process of searching and selecting articles through 4 databases can be seen in Figure 1. The initial search resulted in 1474 articles, then the removal process was carried out from articles that had 671 duplicates, the next process filtered out articles both full text and not, and there were 67 articles in full text but only 9 articles were synthesized. 
Kurniagung et al./ the Effect of Body Mass Index on the Flat Foot Incidence

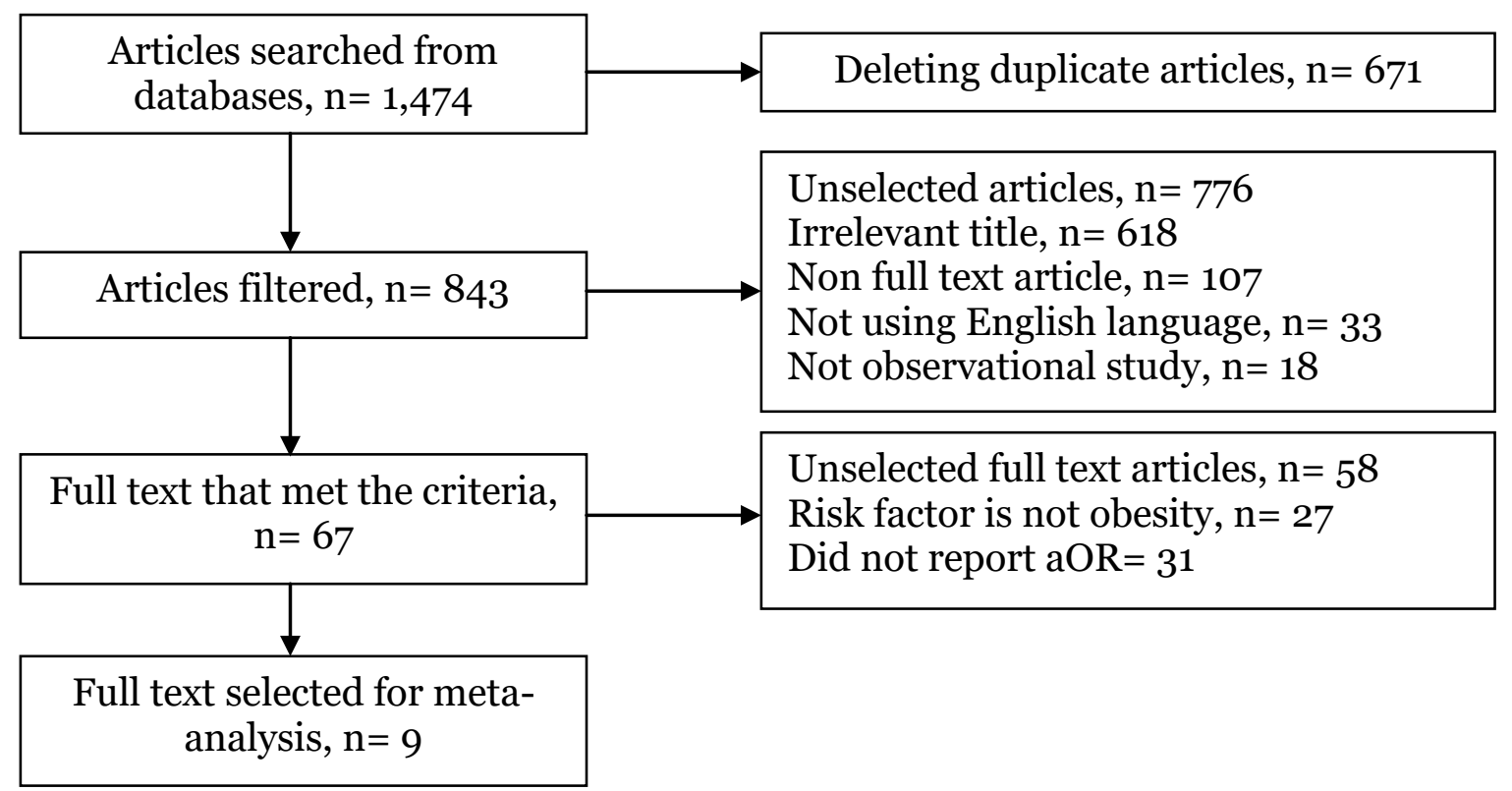

Figure 1. Flowchart of the review process

Figure 2 shows an overview of the research areas used in this meta-analysis which are spread across 3 continents, namely the continents of Africa, Asia and Europe. There were 9 articles in the final review process that met the quantitative requirements and were divided into 3 , namely 4 cross sectional articles, 2 case control articles, and 3 cohort articles according to the flat foot risk factor, namely obesity.

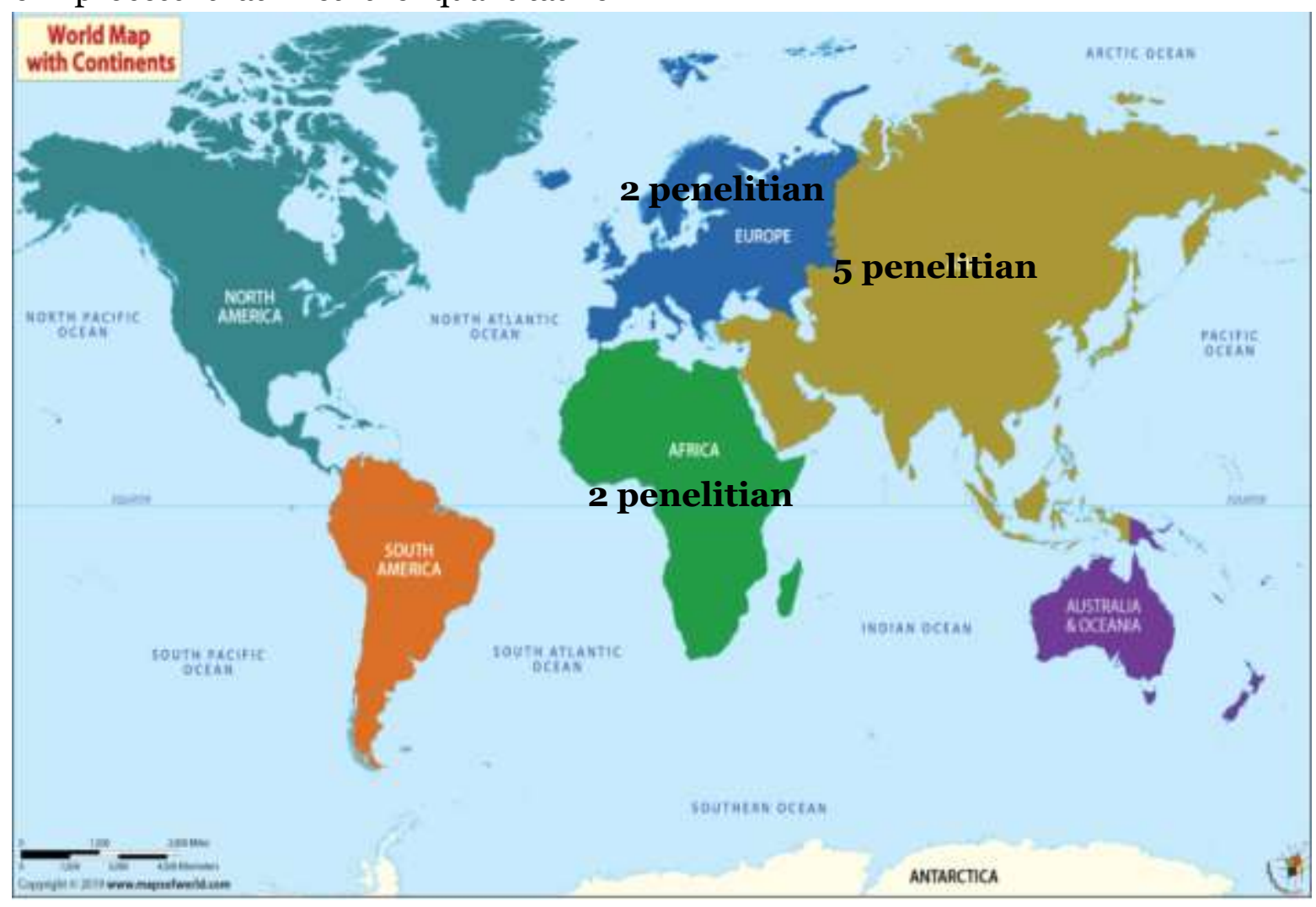

Figure 2. Overview of the research area (World of Maps, 2019) 
Kurniagung et al./ the Effect of Body Mass Index on the Flat Foot Incidence

1. The association of obesity with flat foot cross-sectional study design
There were 4 cross-sectional articles as a reference source for meta-analysis of obesity on flat foot.

Table 1. Summary sources of the effect of obesity on flat foot with a cross-sectional study

\begin{tabular}{|c|c|c|c|c|c|}
\hline $\begin{array}{l}\text { Author } \\
\text { (Year) }\end{array}$ & Location & $\begin{array}{l}\text { Sample } \\
\text { Size }\end{array}$ & Population (P) & $\begin{array}{l}\text { Intervention (I) and } \\
\text { Comparator (C) }\end{array}$ & Outcome \\
\hline $\begin{array}{l}\text { Abich et al. } \\
(2020)\end{array}$ & Ethiopia & 845 & $\begin{array}{l}\text { Children 11-15 } \\
\text { years old }\end{array}$ & $\begin{array}{l}\text { I: obesity } \\
\text { C: normal weight }\end{array}$ & Flat Foot \\
\hline $\begin{array}{l}\text { Alghadir et } \\
\text { al. (2019) }\end{array}$ & Mesir & 550 & $\begin{array}{l}\text { Children 6-12 } \\
\text { years old }\end{array}$ & $\begin{array}{l}\text { I: obesity } \\
\text { C: normal weight }\end{array}$ & Flat Foot \\
\hline $\begin{array}{l}\text { Chang et al. } \\
\text { (2010) }\end{array}$ & Taiwan & 2083 & $\begin{array}{l}\text { Children aged } 7- \\
12 \text { years }\end{array}$ & $\begin{array}{l}\text { I: obesity } \\
\text { C: normal weight }\end{array}$ & Flat Foot \\
\hline $\begin{array}{l}\text { Chen et al. } \\
\text { (2011) }\end{array}$ & Taiwan & 1598 & $\begin{array}{l}\text { Children aged 3-6 } \\
\text { years }\end{array}$ & $\begin{array}{l}\text { I: obesity } \\
\text { C: normal weight }\end{array}$ & Flat Foot \\
\hline
\end{tabular}

\section{a. Forest plot}

Based on Figure 3, it can be seen that obesity increases the incidence of flat foot with $\mathrm{aOR}=3.10 ; 95 \% \mathrm{CI}=1.80$ to $5.32 ; \mathrm{p}=0.001$.
The heterogeneity of the research data shows $\mathrm{I}^{2}=81 \%$ so that the distribution of the data is stated as heterogeneous or the random effect model.

\section{Odds Ratio Odds Ratio}

Study or Subgroup log[Odds Ratio] SE Weight IV, Random, $95 \% \mathrm{Cl} \quad$ IV, Random, $95 \% \mathrm{Cl}$

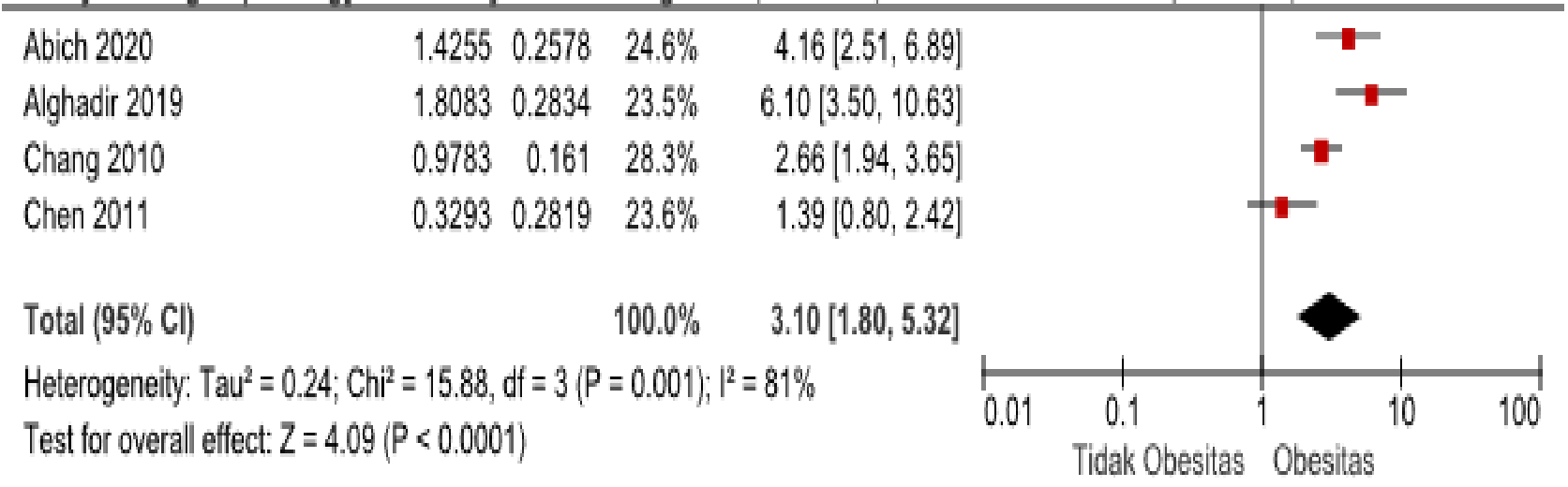

Figure 3. Forest plot obesity against flat foot cross-sectional study design

\section{b. Funnel plot}

Figure 4 shows the absence of publication bias as indicated by the symmetry of the 2 plots on the right and 2 plots on the left symmetrical to each other. The left plot has a standard error of 0.3 to 0.1 , while the right plot is 0.3 . 


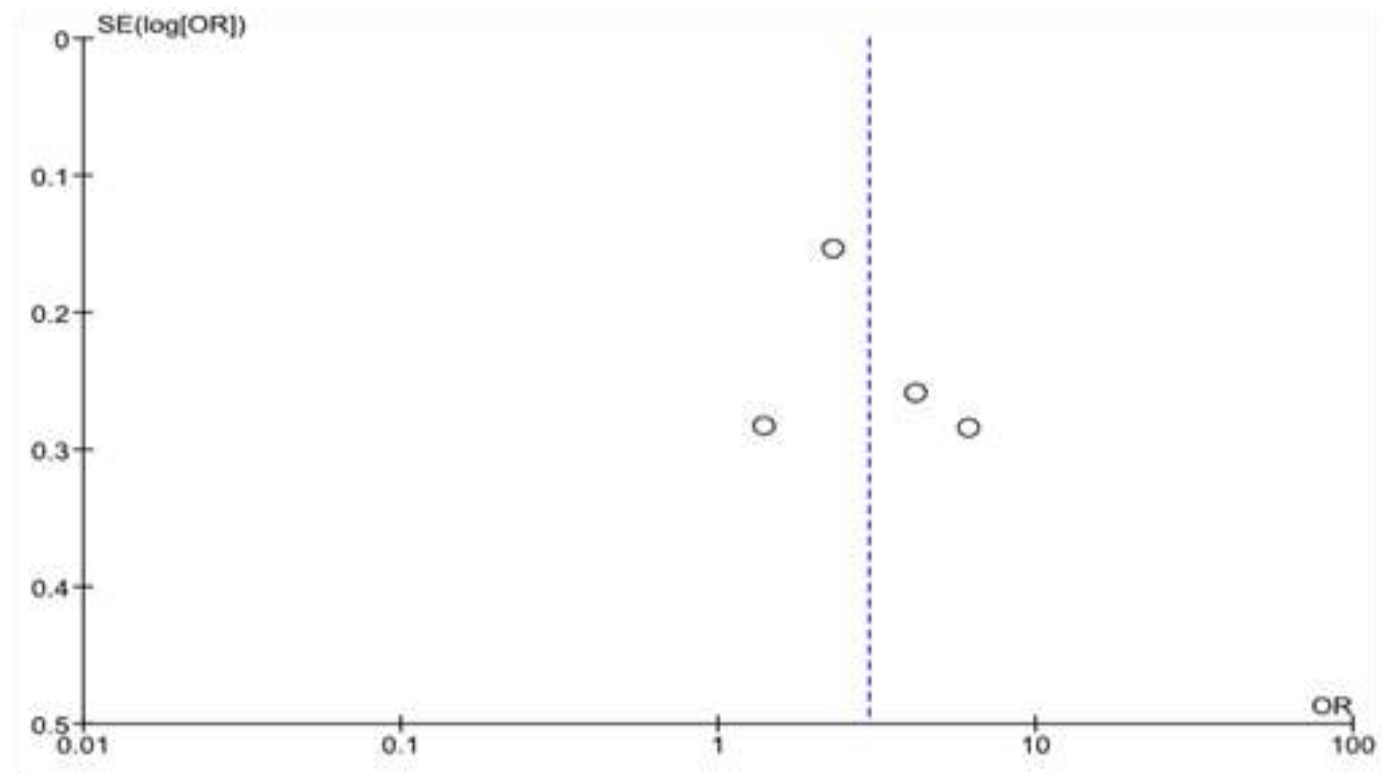

Figure 4. Funnel plot obesity to the flat foot design of the cross-sectional study

2. The relationship between obesity and flat foot design is a casecontrol study
There are 2 case control articles as a source for a meta-analysis study of obesity on the incidence of flat foot worldwide

Table 2. Summary of the source of the effect of obesity on flat foot with a case control design

\begin{tabular}{|c|c|c|c|c|c|}
\hline $\begin{array}{l}\text { Author } \\
\text { (Year) }\end{array}$ & Location & $\begin{array}{l}\text { Sample } \\
\text { Size }\end{array}$ & $\begin{array}{l}\text { Population } \\
\text { (P) }\end{array}$ & $\begin{array}{l}\text { Intervention (I) and } \\
\text { Comparator (C) }\end{array}$ & Outcome \\
\hline $\begin{array}{l}\text { Abdel-Fattah } \\
\text { et al. (2006) }\end{array}$ & $\begin{array}{l}\text { Saudi } \\
\text { Arabia }\end{array}$ & 516 & $\begin{array}{l}\text { Teens aged 18- } \\
21 \text { years }\end{array}$ & $\begin{array}{l}\text { I: obesity } \\
\text { C: normal weight }\end{array}$ & Flat Foot \\
\hline $\begin{array}{l}\text { Asencio et } \\
\text { al. (2019) }\end{array}$ & Spain & 104 & $\begin{array}{l}\text { Children aged } \\
\text { 7-9 years }\end{array}$ & $\begin{array}{l}\text { I: obesity } \\
\text { C: normal weight }\end{array}$ & $\begin{array}{l}\text { Pes planus } \\
\text { valgus foot }\end{array}$ \\
\hline
\end{tabular}

\section{a. Forest plot}

Based on Figure 5, it can be seen that obesity increases the incidence of flat foot with $\mathrm{aOR}=5.49 ; 95 \% \mathrm{CI}=1.33$ to $22.61 ; \mathrm{p}=0.07$, and. The heterogeneity of the research data shows $\mathrm{I}^{2}=69 \%$ so that the distribution of the data is stated as heterogeneous or the random effect model.

Odds Ratio

Odds Ratio

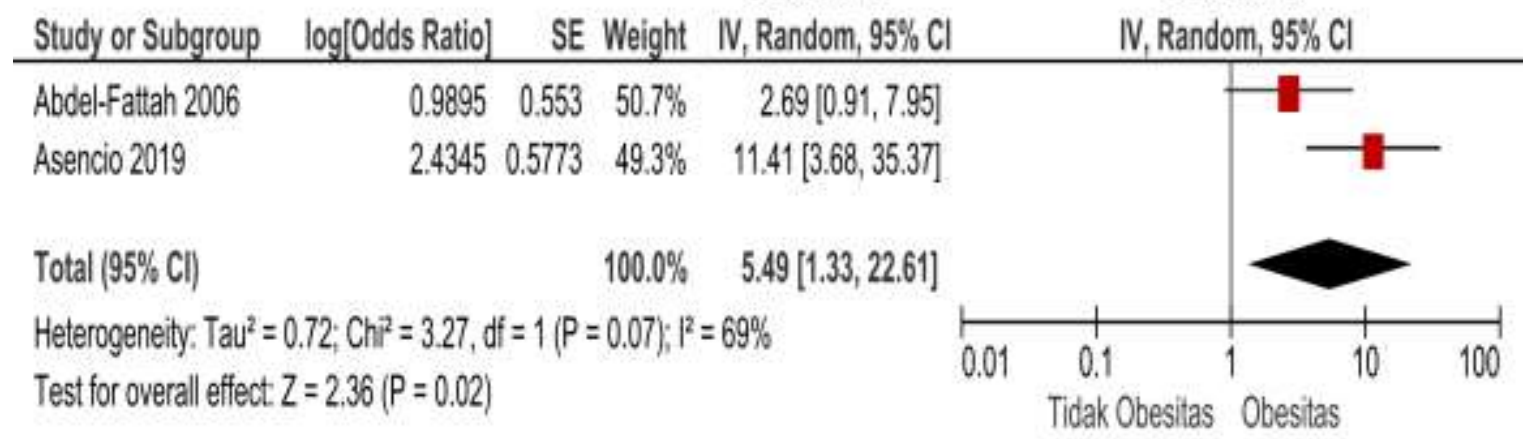

Figure 5. Forest plot obesity against flat foot case-control study design 


\section{b. Funnel plot}

Figure 6 shows the absence of publication bias as indicated by the symmetry of 1 plot

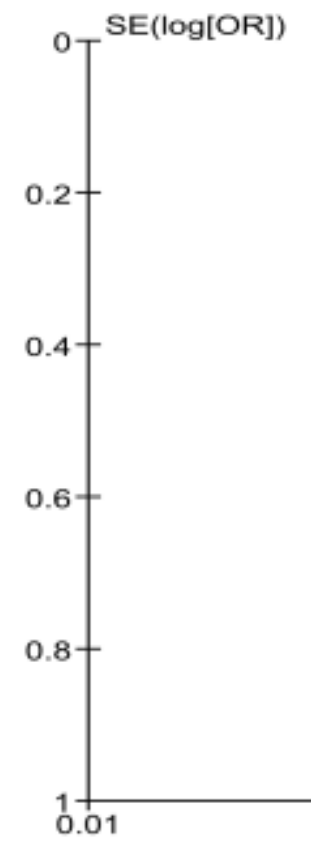

on the right side and 1 plot and the standard error ranges from 0.5 .

Figure 6. Funnel plot of obesity against flat foot case-control study design

3. The relation of obesity with flat foot cohort study design Table 3. Summary of the source of the effect of obesity on flat foot with a cohort design

\begin{tabular}{|c|c|c|c|c|c|}
\hline $\begin{array}{l}\text { Author } \\
\text { (Year) }\end{array}$ & Location & $\begin{array}{l}\text { Sample } \\
\text { Size }\end{array}$ & Population (P) & $\begin{array}{l}\text { Intervention (I) and } \\
\text { Comparator (C) }\end{array}$ & Outcome \\
\hline $\begin{array}{l}\text { Maggio et } \\
\text { al. (2014) }\end{array}$ & Swiss & 774 & $\begin{array}{l}\text { Children aged 2- } \\
17 \text { years }\end{array}$ & $\begin{array}{l}\text { I: obesity } \\
\text { C: normal weight }\end{array}$ & Flat Foot \\
\hline $\begin{array}{l}\text { Maclhuf et } \\
\text { al. (2016) }\end{array}$ & Israel & 113,694 & $\begin{array}{l}\text { Adolescents aged } \\
16-19 \text { years }\end{array}$ & $\begin{array}{l}\text { I: obesity } \\
\text { C: normal weight }\end{array}$ & Flat Foot \\
\hline $\begin{array}{l}\text { Tenenbaum } \\
\text { et al. (2013) }\end{array}$ & Israel & 825,964 & $\begin{array}{l}\text { Adolescents aged } \\
16-19 \text { years }\end{array}$ & $\begin{array}{l}\text { I: obesity } \\
\text { C: normal weight }\end{array}$ & Flat Foot \\
\hline
\end{tabular}

There are 3 cohort articles as a source of meta-analysis of obesity on the incidence of flat foot in the world.

\section{a. Forest Plot}

Based on Figure 7, it can be seen that obesity can increase the incidence of flat foot with $\mathrm{aOR}=1.64 ; 95 \% \mathrm{CI}=1.34$ to 2.02 ; $\mathrm{p}<0.001$. The heterogeneity of the research data shows $\mathrm{I}^{2}=95 \%$ so that the distribution of the data is stated as heterogeneous or the random effect model. 
Kurniagung et al./ the Effect of Body Mass Index on the Flat Foot Incidence

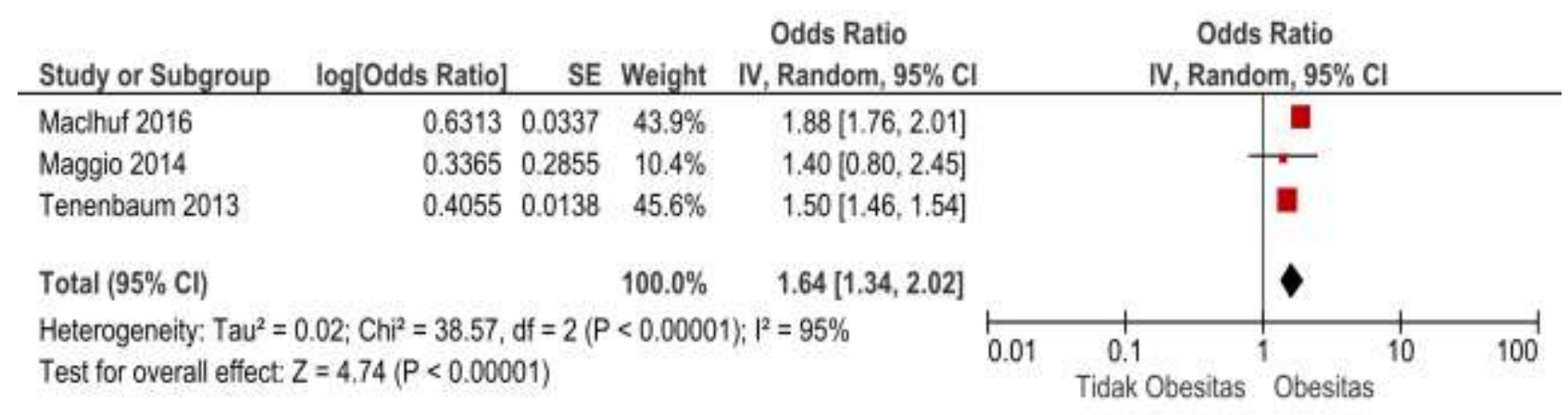

Figure 7. Forest plot of obesity against the flat foot cohort study design

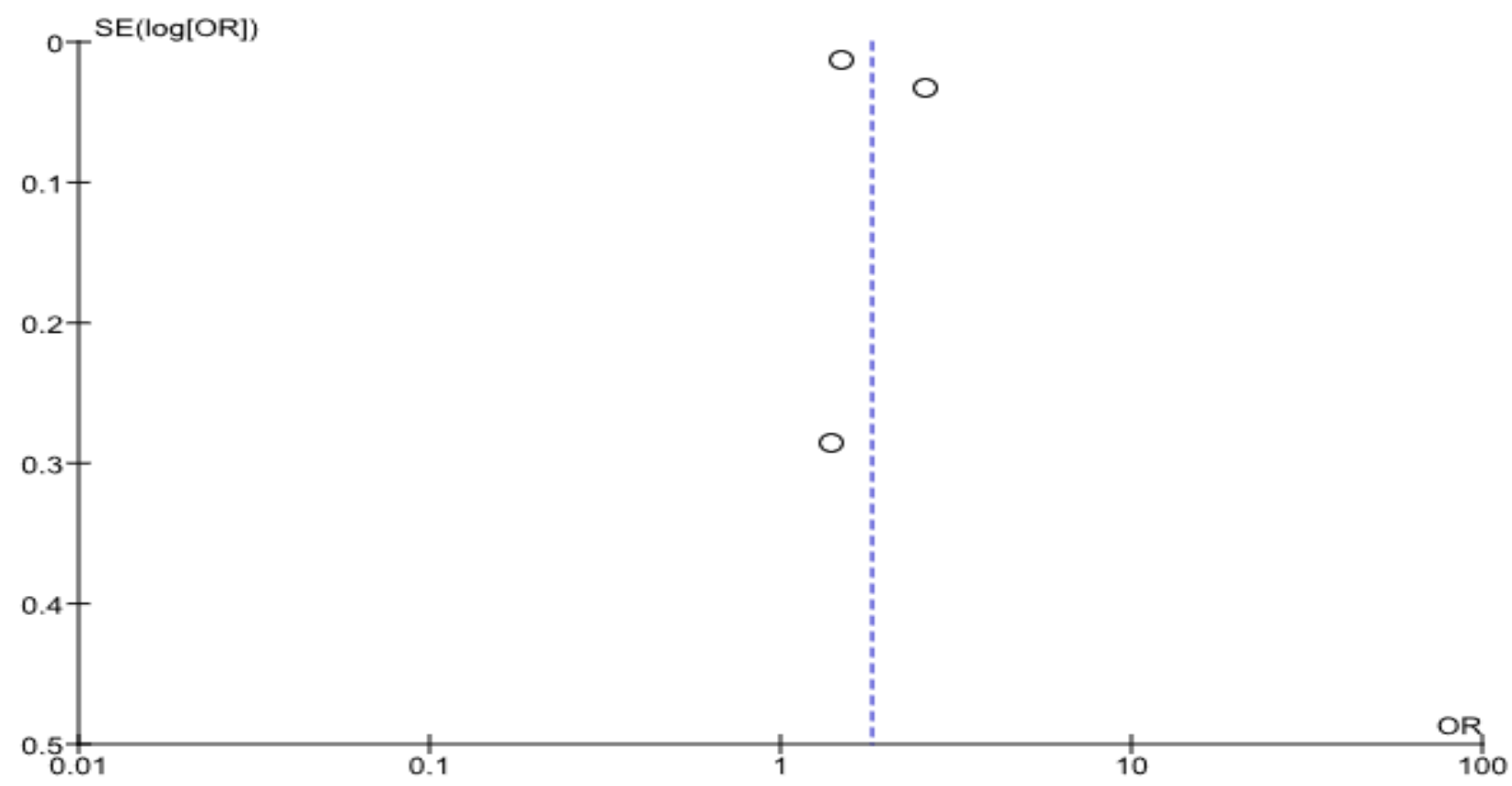

Figure 8. Funnel plot of obesity against the flat foot cohort study design

\section{b. Funnel plot}

Figure 8 shows a publication bias characterized by asymmetry of 1 plot on the right and 2 plots on the left, the standard error ranges from 0.3 to 0.

\section{DISCUSSION}

\section{Obesity to flat foot}

The results of the meta-analysis on the relationship between obesity and flat foot, for the relationship between obesity and flat foot in a cross-sectional study design, were statistically significant with $\mathrm{aOR}=$ $3.10 ; 95 \% \mathrm{CI}=1.80$ to $5.32, \mathrm{p}=0.001$. The number of samples used in the research design of this study was 5.076 people with an age range of 3-15 years. The case-control study design indicated that this study was statistically significant with $\mathrm{aOR}=5.49$; 95\% $\mathrm{CI}=1.33$ to $22.61 ; \mathrm{p}=0.07$. The number of samples used in the research design of this study was 620 people aged 721 years. The cohort study design showed that this was statistically significant with $\mathrm{aOR}=1.64 ; 95 \% \mathrm{CI}=1.34$ to $2.02 ; \mathrm{p}<0.001$. The number of samples used in the research design of this study was 940,432 people aged 2-19 years.

Based on this study, it can be concluded that obese people will increase 
the risk of experiencing flat foot, this is in accordance with research conducted by Fernandez et al, (2017); Pourghasem et al, (2016); Vergara et al, (2012); Pfeiffer et al, (2006).

The foot is a complex joint, 26 bones, and more than 30 joints in it, not only that, the foot also has 3 main functions as a means of movement, absorbing forces from the ground, and supporting body weight. The feet have an important role for biomechanical alignment of the body, especially the lower body organs. Changes in the structure of the feet have been shown to affect the lower limb, namely the flat foot (Shree et al, 2018).

Obesity will affect a person's gait, the feet will receive the support of their body weight when walking, the load on the legs increases 1.2 times when walking and 2-3 times when running. Obese individuals will increase their body weight on the legs 3 times compared to normal weight individuals, this can cause negative changes in biodynamic growth and potentially reduce quality of life and limit physical activity, this can result in weak muscle strength and will limit movements that result in changes in structure and abnormal function in the feet, namely the flat foot (Park \&Park, 2019).

Obese individuals will have a higher pressure on the soles of the feet than individuals with normal weight, the increased pressure on the soles of the feet occurs on the $1^{\text {st }}$ and $2^{\text {nd }}$ metatarsals and on the calcaneus, this causes high pressure on the plantar fascia because it has origins and insertio on the 1st metatarsal. and 2 and calcaneus. The plantar fascia is a network that maintains the shape of the medial longitudinal arch and supports the footwork (Park \& Park, 2019). Flat foot will cause an imbalance when supporting body weight, this is associated with weak muscle strength and reduced joint area (LGS) dorsi flexion of the ankle. If the mechanism lasts a long time, the plantar fascia will thicken due to increased pressure on weight gain (Park et al, 2018).

The area of the junction (LGS) dorsiflexion of the ankle is an important component in maintaining balance when the foot rests body weight on the core contact and the process of walking, especially during the loading response and the middle stance phase (Houglum and Bertoti, 2012; Neumann, 2016). Individuals with obesity will experience reduced calf flexibility this can reduce the area of motion of the ankle dorsiflection joint, which is associated with the valgus ankle angle and limits movement of the dorsiflexion of the ankle, limiting movement of the hind leg creates high mechanical loads on the middle of the foot which results in weakness tendoligamentous structures in the feet (SadeghiDemneh et al, 2018). People with flat feet tend to flex their knees and hip joints to compensate for the reduced LGS dorsiflexion of the ankles, this will have a negative effect in the form of increased energy when walking (Park et al, 2018).

The area of motion of the ankle joint (LGS), the plantar moment of flexion, and reduced joint angular velocity will cause reduced strength of the ankle joint, this will result in achiles tendon shortening (Kim et al, 2017). Achiles tendon shortening is associated with the occurrence of flat foot accompanied by pain (Shibuya et al, 2014).

\section{AUTHOR CONTRIBUTION}

Philipus Prihantiko Kurniagung is the main researcher who chooses topics, collects research data, formulates articles, and processes data. Dono Indarto helped formulate the framework. Setyo Sri Rahardjo formulated the background. 


\section{CONFLICT OF INTEREST}

There is no conflict of interest.

\section{FUNDING AND SPONSORSHIP}

This study is self-funded.

\section{ACKNOWLEDGEMENT}

Researchers are grateful and appreciate the electronic data bases of PubMed, Science Direct, Google Scholar and Springer Link.

\section{REFERENCE}

Abdel-Fattah MM, Hassanin MM, Felembane FA, Nassaane MT (2006). Flat foot among Saudi Arabian army recruits: prevalence and risk factors. East Mediterr Health J. 12(1-2):211-7.

Abich Y, Mihiret T, Yihunie Akalu, Gashaw M, Janakiraman B (2020). Flatfoot and associated factors among Ethiopian school children aged 11 to 15 years: A school-based study. PLOS ONE, 15(8), doi: 10.1371/journal.pone.0238001.

Alghadir AH, Gabr SA, Rizk AA (2019). Plasmatic adipocyte biomarkers and foot pain associated with flatfoot in schoolchildren with obesity. Rev Assoc Med Bras, 65(8): 1061-1066. doi:10.1590/1806-9282.65.8.1061.

Asencio JMM, Medina-Alcántara MF, Ortega-Avila AB, Jimenez-Cebrian AM, Moguer JP, Cervera-Marin JA, GijonNogueron G (2019). Anthropometric and psychomotor development factors linked to foot valgus in children aged 6 to 9 years. J Am Podiatr Med Assoc. 109(1): 30-35. doi:10.7547/16-108.

Butterworth PA, Landorf KB, Smith SE, Menz HB (2012). The association between bodymassindex and musculoskeletal foot disorders: a systematic review. Obes Rev. 13(7): 630642.doi:10.1111/j.1467.
Brunnstrom's clinical kinesiology. 6th NeumannDA. (2016). Kinesiology of the musculoskeletal system: foundations for rehabilitation. 3rd ed. St. Louis (MO): Mosby.

Chang Y, Hung W, Wu H, Chiu Y, Hsu H (2010). Measurements of foot arch in standing, level walking, vertical jump and sprint start. Int Journal of Sport and Exercise Science, (2)2, 31-38.

Chen KC, Yeh CJ, Tung L, Yang JF, Yang SF, Wang CH (2010). Relevant factors influencing flatfoot in preschool-aged children. Eur. J Pediatr. 170(7): 931936. doi:10.1007/soo431-010-1380-7

Dare DM, Dodwell ER (2014). Pediatric flatfoot. Curr Opin Pediatr, 26(1): 93100. doi: 10.1097/mop.0000000000000039.

EzemaCI, AbaraoguUO, Okafor GO (2014). Flat foot and associated factors among primary school children: A cross-sectional study. Hong Kong Physiother J, 32(1), 13-20. doi:10.1016/j.hkpj.2013.05.001.

Fernandez SP, Martin CG, Tajes FA, Pillado, TS, Diaz SP, Garcia SP, Bestilleiro RS, Barreiro VB (2017). Flat foot in a random population and its impact on quality of life and functionality.J clin diagn res. 11(4): doi:10.7860/jcdr/2017/24362.9697.

Houglum PA, Bertoti DB (2012). Brunnstrom's clinical kinesiology. 6th ed. Philadelphia (PA): The F.A Davis Co

Machluf Y, Fink D, Farkash R, Rotkopf R, Pirogovsky A, Tal O, Chaiter Y (2016). Adolescent BMI at Northern Israel. Medicine. 95(12). doi:10.1097/md.oo00000000003022 .

Maggio AB, Martin XE, Saunders Gasser C, Gal-Duding C, Beghetti M, FarpourLambert NJ, Chamay-Weber C (2014). Medical and non-medical complications among children and 
Kurniagung et al./ the Effect of Body Mass Index on the Flat Foot Incidence

adolescents with excessive body weight. BMC Pediatrics, 14(1). doi:10.1186/1471-2431-14-232.

Park SY, Bang HS, Park DJ (2018). Potential for foot dysfunction and plantar fasciitis according to the shape of the foot arch in young adults. J Exerc Rehabil, 14(3), 497-502. doi:10.12965/jer.1836172.086.

Park SY, Park DJ (2019). Comparison of foot structure, function, plantar pressure and balance ability according to the body mass index of young adults. Osong Public Health Res Perspect, 10(2): 102-107. doi: 10.24171/j.phrp.2019.10.2.09

Pfeiffer M, Kotz R, Ledl T, Hauser G, Sluga $M$ (2006). Prevalence of Flat Foot in Preschool-Aged Children. Pediatrics, 118(2): 634-639.doi:10.1542/peds.2005-2126.

Pourghasem M, Kamali N, Farsi M, Soltanpour N (2016). Prevalence of flat foot among school students and its relationship with BMI. Acta Orthop Traumatol Turc, 50(5): 554-557. doi:10.1016/j.aott.2016. 03.002

Sadeghi-Demneh E, Melvin JMA, Mickle K (2018). Prevalence of pathological flatfoot in school-age children. JFoot. (37), 38-44.doi:10.1016/j.foot.2018.05.002 .

Shibuya N, Kitterman RT, LaFontaine J, Jupiter DC (2014). Demographic, physical, and radiographic factors associated with functional flatfoot deformity. J Foot Ankle Surg. 53(2): 168-72. https://doi.org/10.1053/j.jfas.2013.11.002

Shree S, Revathi S, Thiyagarajan A, Kumar D (2018). Does Obesity Cause Flat Foot?. Obes Ther 2(1).

Tenenbaum S, Hershkovich O,Gordon B, Bruck N, Thein R, Derazne E, Afek A (2013). Flexible pes planus in adolescents. Foot Ankle Int, 34(6): 811-817. doi:10.1177/1071100712472327.

Vergara AE, Serrano SRF, Correa PJR, Molano AC, Guevara OA (2012). Prevalence of flatfoot in school between 3 and 10 years. Study of two different populations geographically and socially. Colomb Med. 141-146. doi:10$.25100 / \mathrm{cm} . v 43 \mathrm{i} 2.785$.

Witari NPD, Cahyawati PN, Lestarini A, (2018). Prevalence flatfoot in primary school, IOP Conf Ser Mater Scieng. doi:10.1088/1757899x/434/1/434. 